\title{
Heart rate variability in mine-rescuers in conditions of a simulated emergency response
}

\author{
I.A. Myshchenko ${ }^{1}$, O.I. Soloviov ${ }^{2}$, K.O. Apykhtin ${ }^{2}$ \\ ${ }^{1}$ Ivano-Frankivsk National Medical University; e-mail:kolg.ira21@gmail.com; \\ ${ }^{2}$ State Institution «Kundiev Institute of Occupational Health of the National Academy of Medical \\ Sciences of Ukraine», Kyiv
}

\begin{abstract}
Short-term indices of Heart Rate Variability (HRV) recorded in mine-rescuers men ( $n=18$, mean age $29 \pm 1.4$ years ranged from 22 to 44 years) before and after the simulated emergency response, organized as a competition. Within two hours, mine-rescuers used special rescue equipment, administrated the first medical aid to the conditional victims and performed various tactical tasks. The study group was divided into three subgroups according to the Stress Index (SI) level. Analysis of time-domain and frequency-domain indices of HRV was conducted. The biological age, appropriate biological age and ageing rate were evaluated. It was found out, that the majority of the study group showed signs of neuro-emotional stress even before the competition. Emotional and physical loads caused by the simulated emergency response increased the strain of vegetative adjustment, which grew at the end of the competitions. Rescuers with average levels of SI demonstrated the most sufficient physiological response, while workers with low and high SI levels referred to the risk groups for disadaptation and cardiovascular diseases. Biological age significantly exceeded the population norm. SI and biological age can be recommended to use as additional parameters during medical examinations by the medical services of mine rescue brigades.

Keywords: disadaptation; heart rate variability; mine-rescuers; risk factor; stress index.
\end{abstract}

\section{INTRODUCTION}

Mining is the most hazardous industry in Ukraine, accounting for $18.9 \%$ of the country work-related accidents in 2017, with 936 people injured and 33 killed [1]. The main task of the State Military Mine-Rescue (Emergency Rescue) Service is the elimination of accidents and rescuing people in mines or other potentially hazardous enterprises in conditions of extreme temperatures, chemical/radiation/bacterial pollution, the risk of floods, explosions etc. This occupation requires rigorous professional selection concerning physical and mental health, physical work capacity, thermal tolerance etc. The work process is characterized by the high levels of energy expenditure, lifting or shifting of heavy loads, forced posture, body bents, usage of personal protective equipment (self-contained breathing apparatus, chemical suits), physical strain and nervous-emotional

(C) I.A. Myshchenko, O.I. Soloviov, K.O. Apykhtin stress, irregular or rotating working shifts, etc. Performance of such type of work under the impact of physical and chemical occupational factors (toxic gases, smoke inhalation, fire, explosions, noise, changes of atmospheric pressure, high temperature) can lead to workrelated pathology and occupational diseases because a body can adapt to such factors only to some extent. Physiological adaptation to extreme work conditions heavily depends on individual characteristics. That is why the assessment of earlier signs of disadaptation is highly important for the prediction of all kinds of occupational pathology and readiness to the work. The cardiovascular system reacts immediately to the variation of intrinsic and extrinsic factors. Heart rate variability (HRV) indices were proved to be reliable and significant parameters for the degree of adaptation, diagnosis and prognosis of pathological states [2]. Mine-rescuers must commit regular training in order to be prepared 
for potential emergencies and to react optimally in the real situation. Such training also gives an opportunity to evaluate the physiological response of employees' organisms because in a real emergency it may not be feasible. Stress Index (SI), or index of physiological strain, which is widely used in post-Soviet countries, is sensitive to the central (sympathetic) chain which increases during mental or physical stress. It allows distinguishing groups of people with different kinds of vegetative regulation as a response to the stress level.

The aim of the study was to analyze the direction of changes in heart rate variability in mine-rescuers with different levels of SI in response to physical and emotional stresses caused by a simulated emergency response for the identification of workers with risk of disadaptation; establishing a link between the biological age and the changes in the HRV; working out recommendations for the mine-rescue medical service.

\section{METHODS}

The study group included 18 absolutely healthy male participants who had undergone professional selection, including rigorous pre-employment medical examination. The competition involved a search and rescue response exercise between two mine rescue teams from Myrnohrad and Kryviy Rih cities (Ukraine), conducted according to the schedule in June 2017. During tactical training, which lasted for 2 hours, the workers used special rescue equipment, provided the first medical aid to the conditional victims and performed various tactical tasks. The mean chronological age of the studied participants was $29 \pm 1.4$ years ranged from 22 to 44 years. The total term of service of the workers was $8.7 \pm 1.52$ years, while the term of employment in the rescue service was $3.1 \pm 0.56$ years. The rescuers surveyed were divided into three subgroups, depending on the value of SI [3].

Subgroup I included individuals with low SI (SI $\leq 50$ units $)-22 \%(\mathrm{n}=4)$; subgroup II - with average values of SI $(50 \leq \mathrm{SI} \leq 200$ units $)-56 \%$ $(\mathrm{n}=10)$; subgroup III with high SI values ( $\mathrm{SI} \geq 200$ units) $-22 \%(\mathrm{n}=4)$. According to the literature [4], the level of $\mathrm{SI} \leq 50$ units indicates the prevalence of vagotonia in regulation of the heart rhythm; individuals with SI within 50-200 belong to the group of normotonia; $\mathrm{SI} \geq 200$ points on the prevalence of sympathetic nervous system.

There was no significant difference between the specified subgroups according to the age, total work experience, work experience in rescue service, BMI and biological age.

The functional state of the cardiovascular system based on HRV changes was analyzed before and after the competition. The CardioMood software system developed by the Glushkov Institute of Cybernetics of the National Academy of Sciences of Ukraine with heart rate sensors Polar H-7 was used to register cardiograms and to calculate the HRV indices. The last ones were recorded within 5 minutes before and after the competition. Heart rate parameters were analyzed following the Task Force of the European Society of Cardiology

Table 1. Characteristics of the study group according to the level of Stress Index

\begin{tabular}{|l|c|c|c|}
\hline \multicolumn{1}{|c|}{ Variable } & $\begin{array}{c}\mathrm{SI} \leq 50 \\
\text { units }\end{array}$ & $\begin{array}{c}50 \leq \mathrm{SI} \leq 200 \\
\text { units }\end{array}$ & $\begin{array}{c}\mathrm{SI} \geq 200 \\
\text { units }\end{array}$ \\
\cline { 2 - 4 } & $(\mathrm{n}=4 ; 22.2 \%)$ & $(\mathrm{n}=10 ; 55.6 \%)$ & $(\mathrm{n}=4 ; 22.2 \%)$ \\
\hline Age, years & 28.3 & 29.8 & 29.5 \\
Total experience, years & 6.2 & 9.6 & 8.8 \\
Experience in mine rescue service, years & 4.0 & 4.9 & 5.4 \\
Body Mass Index & 25.5 & 25.4 & 30 \\
Biological age, years & 48.3 & 45.5 & 43.5 \\
\hline
\end{tabular}


and the North American Society of Pacing and Electrophysiology (1996) [5]. 32 time- and frequency-domain indicators of HRV were selected for analysis [6,7]. Stress index (SI) was calculated according to the formula suggested by Baevsky [8].

The Stress index (SI) was calculated by the formula:

$$
S I=\left(\frac{A M o}{2 M o}\right) \cdot M x D M n
$$

where: Amo - mode amplitude, Mo - mode, MxDMn - variation range.

The biological age (BA) and an appropriate biological age (ABA) of the workers were evaluated according to the method by V. Voytenko developed at the Institute of Gerontology (Kyiv, 1984) [9] using the formulas:

$$
\begin{aligned}
& B A=26.985+0.215 \cdot S P-0.149 \cdot B H+ \\
& 0.723 \cdot S E H-0.151 \cdot S B
\end{aligned}
$$

$$
A B A=0.629 \cdot C A+18.6
$$

where SP - systolic pressure, BH - breath holding, SEH - subjective estimation of health, SB - static balancing, CA - chronological age.

The ageing rate was calculated as a difference between BA and ABA. The significance of the changes in the HRV indices was calculated using Student t-test, the correlation was established using the Brave-Pearson coefficient, and its validity was established by Student t-test.

\section{RESULTS}

Physiological response to training conditions was different depending on the type of vegetative regulation. The average heart rate in group I was $67.55 \pm 3.58$ beats $/ \mathrm{min}$, in II $-79.06 \pm$ 3.4 beats/min, in III $-89.49 \pm 4.5$ beats $/ \mathrm{min}$, corresponding to the age norm in $65-80$ beats/ min. The significant difference in the average HR was between I and III groups $(\mathrm{P}<0.05)$.

Stress Index (SI) had significant correlations with the most of studied HRV parameters (Table 2) both before and after the competition. Such correlation was found for the majority of timeand frequency-domain indices, as well as for VLF/HF ratio, which reflect the prevalence of subcortical sympathetic centres over vagal activity.

During the analysis, the specific set of HRV parameters identifying each group was established (Table 3). Thus, individuals with low SI had significantly higher values of all time-domain indices (the average duration of RR intervals, SDNN, RMSSD, pNN50, HRVTi, and mode), except the mode amplitude. Such a physiological response was provided by the prevalence of parasympathetic effects in heart rate regulation at the pre-start stage. However, the rescuers with high values of the SI showed

\begin{tabular}{|c|c|c|c|c|c|c|c|c|}
\hline \multirow[t]{2}{*}{ Variable } & \multicolumn{2}{|c|}{$\begin{array}{l}\text { Correlation } \\
\text { coefficients }\end{array}$} & \multirow[t]{2}{*}{ Variable } & \multicolumn{2}{|c|}{$\begin{array}{l}\text { Correlation } \\
\text { coefficients }\end{array}$} & \multirow[t]{2}{*}{ Variable } & \multicolumn{2}{|c|}{$\begin{array}{l}\text { Correlation } \\
\text { coefficients }\end{array}$} \\
\hline & Before & After & & Before & After & & Before & After \\
\hline HR & 0.79 & 0.63 & WN4 & -0.59 & -0.66 & VLF & -0.54 & -0.75 \\
\hline $\mathrm{mRR}$ & -0.72 & -0.65 & WN5 & - & -0.74 & $\ln (\mathrm{VLF})$ & -0.77 & -0.6 \\
\hline SDNN & -0.48 & -0.72 & $\mathrm{TP}$ & -0.73 & -0.62 & VLF/HF & - & 0.72 \\
\hline RMSSD & -0.56 & -0.64 & $\ln (\mathrm{TP})$ & -0.75 & -0.71 & LF\% & - & -0.47 \\
\hline pNN50 & -0.62 & -0.55 & $\mathrm{HF}$ & -0.53 & -0.57 & VLF\% & - & 0.63 \\
\hline MxDMn & -0.56 & -0.77 & $\ln (\mathrm{HF})$ & -0.53 & -0.75 & A & 0.85 & 0.89 \\
\hline HRVTi & -0.76 & -0.8 & $\mathrm{LF}$ & - & -0.63 & IC & - & 0.65 \\
\hline WN1 & -0.52 & -0.72 & $\ln (\mathrm{LF})$ & -0.75 & -0.51 & & & \\
\hline
\end{tabular}
an opposite reaction. The values of mode ampli-

Table 2. Values of the correlation coefficients between the Stress Index (SI) and the indicators of the HRV before and after the competition

Coefficients are significant at $\mathrm{P}<0.05$ 
tude in the III group exceeded the same index in group I by 2.3 times. On the contrary, the other time-domain parameters in the III group were significantly lower than in group I (by 2.8 times (SDNN), 2.6 times (HRTVi) and even by 22.1 times (pNN50).

However, considering the spectral characteristics of the HRV in rescuers of Group I, it becomes clear that such an adaptation reserve is of high physiological price. Thus, the frequencydomain indices of HRV in rescuers with low SI values were significantly higher. For instance, the average TP of the spectrum was $8401.5 \pm$ $1237.5 \mathrm{~ms}^{2}$, significantly exceeding not only the corresponding values in groups II and III (by 2.44 and 7.9 times, correspondingly) but, also, the physiological norm showing the state of the vegetative dysfunction. Although the level

Table 3. The levels of HRV indices in rescue groups depending on the value of the Stress Index (SI) before the competition, $(\mathrm{M} \pm \mathrm{SD})$

\begin{tabular}{|c|c|c|c|c|}
\hline \multirow{2}{*}{ Index } & \multicolumn{3}{|c|}{ Mean value in the subgroups with different level of SI } & \multirow{2}{*}{$\begin{array}{l}\text { Mean value in the } \\
\text { study group }\end{array}$} \\
\hline & $\mathrm{I}$ & II & III & \\
\hline \multicolumn{5}{|c|}{ Time-domain } \\
\hline SI & $40.3 \pm 4.36^{*}$ & $110.34 \pm 18.41 * *$ & $318.3 \pm 48.68 * * *$ & $141 \pm 26.6$ \\
\hline $\mathrm{mRR}$ & $908.8 \pm 41.15^{*}$ & $784 \pm 38.6 * *$ & $615.9 \pm 26.62 * * *$ & $744.4 \pm 33.78$ \\
\hline SDNN & $89.7 \pm 6.12$ & $75.9 \pm 18.41 * *$ & $32 \pm 3.73 * * *$ & $69.2 \pm 11.44$ \\
\hline RMSSD & $51.5 \pm 2.14 *$ & $31.6 \pm 3.22 * *$ & $19.2 \pm 5.51 * * *$ & $33.3 \pm 3.5$ \\
\hline pNN50 & $28.6 \pm 4.8^{*}$ & $10.5 \pm 2.99 * *$ & $1.3 \pm 0.70 * * *$ & $12.5 \pm 2.96$ \\
\hline MxDMn & $350 \pm 25$ & $290 \pm 44.6 * *$ & $162 \pm 10.8 * * *$ & $275.0 \pm 29.74$ \\
\hline HRVTi & $18.4 \pm 0.71^{*}$ & $12.1 \pm 0.89 * *$ & $6.9 \pm 0.44 * * *$ & $12.34 \pm 1.05$ \\
\hline Mo & $912.5 \pm 32.47 *$ & $755 \pm 40.62 * *$ & $587.5 \pm 32.47 * * *$ & $752.8 \pm 35.48$ \\
\hline Amo & $24.9 \pm 1.19 *$ & $37.1 \pm 1.93 * *$ & $58.1 \pm 5.18 * * *$ & $39.03 \pm 3.10$ \\
\hline WN1 & $394.5 \pm 22.35$ & $331.3 \pm 70.43 * *$ & $162.1 \pm 21.61 * * *$ & $307.7 \pm 44.17$ \\
\hline WN4 & $121.1 \pm 11.22$ & $116.4 \pm 7.9 * *$ & $78.1 \pm 2.76 * * *$ & $108.9 \pm 6.43$ \\
\hline WN5 & $56.6 \pm 16.19$ & $90.6 \pm 8.1$ & $60.5 \pm 5.07 * * *$ & $76.4 \pm 0.25$ \\
\hline \multicolumn{5}{|c|}{ Frequency-domain } \\
\hline $\mathrm{TP}$ & $8401.5 \pm 1237.5^{*}$ & $3440.7 \pm 350^{* *}$ & $1058.6 \pm 237.28 * * *$ & $4,014 \pm 1,999$ \\
\hline $\ln (\mathrm{TP})$ & $8.9 \pm 0.165$ & $8.3 \pm 0.28 * *$ & $6.8 \pm 0.22 * *$ & $8.14 \pm 0.24$ \\
\hline $\mathrm{HF}$ & $1093.3 \pm 214,78^{*}$ & $377.8 \pm 76.82 * *$ & $138.6 \pm 60.88$ & $483.7 \pm 106.42$ \\
\hline $\ln (\mathrm{HF})$ & $6.9 \pm 0.18$ & $6.1 \pm 0.5^{* *}$ & $4.5 \pm 0.45 * * *$ & $5.9 \pm 0.35$ \\
\hline LF & $2591.7 \pm 334.8$ & $2883 \pm 1201.74 * *$ & $457.4 \pm 209.53$ & $2,279,25 \pm 711.94$ \\
\hline $\ln (\mathrm{LF})$ & $7.83 \pm 0.125$ & $7.52 \pm 0.25^{* *}$ & $5.74 \pm 0.43 * * *$ & $7.19 \pm 0.25$ \\
\hline VLF & $4716.5 \pm 922.38 *$ & $1794.9 \pm 527.46^{* *}$ & $462.6 \pm 82.72 * * *$ & $2,148 \pm 505.84$ \\
\hline $\ln (\mathrm{VLF})$ & $8.36 \pm 0.23 *$ & $7.19 \pm 0.23 * *$ & $6.07 \pm 0.18^{* * *}$ & $7.2 \pm 0.23$ \\
\hline $\mathrm{LF} \%$ & $31.8 \pm 2.3 *$ & $48.9 \pm 5.26$ & $38 \pm 9.4$ & $42.7 \pm 4.02$ \\
\hline VLF\% & $54.6 \pm 4.9 *$ & $35.74 \pm 4.59$ & $48.83 \pm 10.21$ & $42.9 \pm 4.03$ \\
\hline $\mathrm{A}$ & $0.31 \pm 0.02 *$ & $0.42 \pm 0.015^{* *}$ & $0.56 \pm 0.032 * * *$ & $0.43 \pm 0.023$ \\
\hline
\end{tabular}

*the difference between I and II subgroups is significant at $\mathrm{P}<0.05$;

** the difference between II and III subgroups is significant at $\mathrm{P}<0.05$;

*** the difference between I and III subgroups is significant at $\mathrm{P}<0.05$ 
of high-frequency oscillations was significantly higher than those recorded in workers with an average and high SI, it is necessary to notice to abnormally high levels of VLF components in rescuers of Group I $(54.6 \pm 4.9 \%)$. Despite the fact that the question of the nature of these fluctuations is still being discussed, they have a strong association with cardiovascular diseases prognosis, and mortality [10]. However, the registered physiological reaction requires further research.

In general, the initial HRV indexes, recorded before competitions, do not correspond to the initial ones in the state of rest [11]. Obviously, the pre-start reaction in all rescuers effected significantly the state of the CVS. In this sense, the physiological response in the group of rescuers with average SI values comparing with the I and III groups was more adequate.

The analysis of the HRV indices after the competitions showed dramatic fluctuations that affected the difference significance. Nevertheless, significant difference between I and III group was found in such indices as SDNN, RMSSD, HRVTi, Amo, WN5, TP, In (TP), ln (HF), ln (LF) and LF\% (Table 4).

Analysis of human functional states and their prediction should be based on an integrated approach. A comparison of physiological parameters with the population norm according to sex and age does not take into account some individual biological features. One of them is the biological age (BA). If the chronological age (CA) of workers ranged from 22 to 44 years and was $29 \pm 1.4$ years in average, the BA in this study group ranged 23.3 to 57.8 years with the mean

Table 4. Values of HRV indices in rescue groups depending on the level of Stress Index (SI) after the competition, (M \pm SD)

\begin{tabular}{|c|c|c|c|c|}
\hline \multirow[t]{2}{*}{ Index } & \multicolumn{3}{|c|}{ Mean value in the groups with different level of SI } & \multirow{2}{*}{$\begin{array}{l}\text { Mean value in the } \\
\text { study group }\end{array}$} \\
\hline & I & II & III & \\
\hline \multicolumn{5}{|c|}{ Time-domain } \\
\hline SDNN & $48.8 \pm 9.8$ & $36.2 \pm 6.99 * *$ & $21.4 \pm 2.04$ & $35.7 \pm 4.95$ \\
\hline RMSSD & $10.7 \pm 1.57$ & $7.4 \pm 1.00 * *$ & $5.3 \pm 0.86$ & $20.2 \pm 3.8$ \\
\hline pNN50 & $10.22 \pm 6.51$ & $4.66 \pm 2.35$ & $0.15 \pm 0.12 * * *$ & $4.9 \pm 2.13$ \\
\hline MxDMn & $250 \pm 35.35 *$ & $174.17 \pm 17.5^{* *}$ & $137.5 \pm 13.32 * * *$ & $182.9 \pm 15.7$ \\
\hline HRVTi & $89.84 \pm 6.48$ & $90.89 \pm 14.6^{* *}$ & $60.55 \pm 6.40$ & $7.65 \pm 0.80$ \\
\hline Amo & $43.11 \pm 5.22$ & $60.57 \pm 6.3 * *$ & $77.09 \pm 5.8$ & $60.36 \pm 4.76$ \\
\hline WN1 & $214.84 \pm 83.66$ & $192.32 \pm 33.53$ & $95.7 \pm 12.75 * * *$ & $175.9 \pm 23.23$ \\
\hline WN5 & $28.87 \pm 7.71$ & $21.98 \pm 5.18 * *$ & $60.55 \pm 0.59 * * *$ & $66.4 \pm 8.89$ \\
\hline \multicolumn{5}{|c|}{ Frequency-domain } \\
\hline TP & $2,722.37 \pm 1030.82$ & $1,804.4 \pm 786.13 * *$ & $470.67 \pm 68.27$ & $1,712 \pm 524.9$ \\
\hline $\ln (\mathrm{TP})$ & $7.60 \pm 0.41$ & $7.06 \pm 0.42 * *$ & $6.11 \pm 0.16$ & $6,9 \pm 0,28$ \\
\hline $\mathrm{HF}$ & $271.96 \pm 146.18$ & $225.09 \pm 83.73$ & $31.44 \pm 6.88 * * *$ & $192.5 \pm 61.59$ \\
\hline $\ln (\mathrm{HF})$ & $5.06 \pm 0.5$ & $4.79 \pm 0.54 * *$ & $3.29 \pm 0.32$ & $4.5 \pm 0.37$ \\
\hline $\ln (\mathrm{LF})$ & $7.22 \pm 0.42$ & $6.23 \pm 0.47 * *$ & $5.21 \pm 0.23$ & $6.22 \pm 0.32$ \\
\hline LF\% & $68.59 \pm 2.99 *$ & $45.62 \pm 4.4^{* *}$ & $42.29 \pm 6$ & $50 \pm 3.77$ \\
\hline VLF\% & $23.1 \pm 3.69^{*}$ & $40.69 \pm 4.33$ & $50 \pm 7.5$ & $38.9 \pm 3.65$ \\
\hline
\end{tabular}

* the difference between I and II subgroups is significant at $\mathrm{P}<0.05$;

** the difference between II and III subgroups is significant at $\mathrm{P}<0.05$;

$* * *$ the difference between I and III subgroups is significant at $\mathrm{P}<0.05$ 
age $45.74 \pm 1.8$ years. A variety of morphological and functional changes take place in the course of body ageing. In the first instance, they involve the cardiovascular system which exhibits high lability. From this point of view, the BA reflects the character of adaptation reactions much better than the CA. An appropriate biological age is the population standard corresponding to the average ageing rate in the proper chronological age. The obtained results show that the BA and the difference between the BA and an appropriate biological age (ABA) correlate significantly with the HRV indices (Table 5), which allow to recommend them as additional ones.

The obtained data indicate that CA correlate with HRV after the competitions, reflecting the body response to the two-hour emotional and physical activity, while the BA correlate with the spectral components of the HRV before the beginning of the competition, which can be used in practical work to assess the adaptive reserve of the body.

\section{DISCUSSION}

The profession of mine-rescues belongs to jobs with high physical and psycho-emotional stress. After a rigorous professional selection, only absolutely healthy people are admitted to such work. Nevertheless, the examination conducted by Tomaskova H. et al. [12] in the group of 685 mine-rescuers which included electrocardiography at rest, basic anthropometric and biochemical tests allowed the authors to conclude that the prevalence of cardiovascular diseases in this study group is comparable with that one in the general population. Taking into account that the mean term of service of rescues in the mentioned study was quite high, the obtained results can be explained by the impact of working conditions. This point of view is confirmed by our results. In general, cardiovascular risk is associated with low or excessive fluctuations of N-N intervals. Considering changes of time-domain indices caused by the elimination of a simulated emergency, it is necessary to underline, that significantly increased heart rate after the competition indicates a reduction in the effectiveness of the heart muscle. As heart rate rises due to a decrease in the duration of a general cardiac pause and a decrease in the duration of diastole, this impairs the blood supply to the myocardium. A significant decrease in the average duration of RR ( $m$ RR) intervals at this background (Table 3) points to increasing sympathetic effects in the regulation of the heart rate. This was confirmed by significant reduction in other time-domain indices, namely SDNN, RMSSD, pNN50, MxDMn after the competition. In 2010 Nunan et al. [11] published normal values for short HRV records obtained in 21,438 healthy participants.

Table 5. Correlation coefficients between HRV and chronological (CA), biological (BA) age and ageing rate

\begin{tabular}{|c|c|c|c|c|c|c|c|c|c|}
\hline \multirow[t]{2}{*}{$\begin{array}{l}\text { Chronological } \\
\text { age }\end{array}$} & $\begin{array}{l}\text { mR-R } \\
\text { after }\end{array}$ & $\begin{array}{l}\text { SDNN } \\
\text { after }\end{array}$ & $\begin{array}{l}\text { HRTVi } \\
\text { after }\end{array}$ & $\begin{array}{l}\text { WN1 } \\
\text { after }\end{array}$ & $\begin{array}{l}\text { WN4 } \\
\text { after }\end{array}$ & $\begin{array}{l}\text { WN5 } \\
\text { after }\end{array}$ & $\begin{array}{c}\mathrm{TP} \\
\text { after }\end{array}$ & $\begin{array}{l}\text { VLF } \\
\text { after }\end{array}$ & $\begin{array}{c}\mathrm{LF} \\
\text { after }\end{array}$ \\
\hline & $\begin{array}{c}0.46 \\
\mathrm{P}<0.05\end{array}$ & $\begin{array}{c}0.54 \\
\mathrm{P}<0.05\end{array}$ & $\begin{array}{c}0.50 \\
\mathrm{P}<0.05\end{array}$ & $\begin{array}{c}0.49 \\
\mathrm{P}<0.05\end{array}$ & $\begin{array}{c}0.677 \\
\mathrm{P}<0.01\end{array}$ & $\begin{array}{c}0.589 \\
\mathrm{P}<0.02\end{array}$ & $\begin{array}{c}0.589 \\
\mathrm{P}<0.02\end{array}$ & $\begin{array}{c}0.62 \\
\mathrm{P}<0.01\end{array}$ & $\begin{array}{c}0.59 \\
\mathrm{P}<0.02\end{array}$ \\
\hline \multirow[t]{2}{*}{ Biological age } & $\begin{array}{l}V L F, \% \\
\text { before }\end{array}$ & $\begin{array}{l}V L F / L F \\
\text { before }\end{array}$ & $\begin{array}{l}\ln L F \\
\text { before }\end{array}$ & & & & & & \\
\hline & $\begin{array}{c}-0.55 \\
\mathrm{P}<0.02\end{array}$ & $\begin{array}{c}-0.55 \\
\mathrm{P}<0.02\end{array}$ & $\begin{array}{c}0.50 \\
\mathrm{P}<0.05\end{array}$ & & & & & & \\
\hline \multirow[t]{2}{*}{ Ageing rate } & $\begin{array}{l}L F / L F \\
\text { before }\end{array}$ & $\begin{array}{l}\ln L F \\
\text { before }\end{array}$ & & & & & & & \\
\hline & $\begin{array}{c}-0.47 \\
\mathrm{P}<0.05\end{array}$ & $\begin{array}{c}0.50 \\
\mathrm{P}<0.05\end{array}$ & & & & & & & \\
\hline
\end{tabular}


Comparing initial values in the study group of mine-rescues with normal values suggested by Nunan et al. it becomes clear, that such indices as mRR and RMSSD were significantly lower than physiological norms for healthy people while SDNN exceeded the norm. At the same time, the standard deviation of NN intervals (SDNN) after the competition below $20 \mathrm{~ms}$ was registered in $16.6 \%$ of participants. It can be considered as the prognosticator sign of cardiovascular complications and pathology [13]. The mode amplitude (Amo) was reported to be one of the most important indexes [14] because of its resistance to artefacts and sensitivity to the functional state of the body. The initial values of Amo were quite high. The value of Amo more than $50 \%$, which regarded as a reaction to high nervous-emotional stress, was registered in $16.6 \%$ of the participants before and in $77.8 \%$ of employees after the competition. The absolute value of mode decreased significantly to $145.8 \mathrm{~ms}$ against the substantial increase in its amplitude, indicating a stabilization of the heart rhythm under the influence of the sympathetic nervous system.

The Task Force of The European Society (1996) suggests normal values of frequencydomain parameters for the short-term recording. According to them, TP should be at the level $3,466 \pm 1,018 \mathrm{~ms}^{2}$, which is comparable with our results obtained before the competitions $\left(4,014 \pm 1,999.2 \mathrm{~ms}^{2}\right)$. The initial values of TP in $22.2 \%$ of rescuers exceeded $6,000 \mathrm{~ms}^{2}$, which is considered to be a state of autonomic dysfunction. According to existing classification [13], the value of TP which exceeds $6,000 \mathrm{~ms}^{2}$, points on increasing of the functional reserve (the state of excessive reaction that requires recovery of the energy balance). In our opinion, this can partly be due to the pre-starting reaction and high expectation of the competition's results (motivation to win was encouraged by a generous financial incentive). It should be noted that the power of HF fluctuations was lower than the norm suggested by The Task Force while LF and especially VLF exceeded them. According to the literature $[8,13]$ in a healthy person, the part of the VLF power does not exceed 30-45\%. Although the nature of this component is still under discussion, most scientists associate it with the most ancient evolutionary way of regulation - the humoral one. In fact, if other mechanisms do not work, the body uses its last reserve. The amplitude of these waves correlates also with the psycho-emotional tension and functional state of the cerebral cortex. It several studies it is shown that VLF power is more strongly associated with all-cause mortality and may be fundamental for health $[10,15,16]$.

According to the literature [17], reduced HRV caused by the inhibition of parasympathetic activation increases vulnerability to future stress. These results allow us to refer workers with high SI to the group with risk of the failure of adaptation processes.

The comparison of average levels of timeand frequency domain measures between these subgroups has shown an inadequate physiological response caused by the elimination of simulated emergency in rescuers not only with very high levels of SI but those ones who had $\mathrm{SI}<50$ units (Tables 3,4 ). The obtained results contradict the theory that low levels of the SI indicate a stable adaptation [18]. On one hand, it was shown [19] that emotionally, vagotonia could reflect a reduced fear response and increased control over the emotional reactivity. On the other hand, the most important question is what physiological price an organism pays for it. The analysis of time- and frequency-domain parameters allowed to conclude that rescuers with low SI had higher variability of the heart rhythm. For instance, SDNN, RMSSD, MxDMn, TP, VLF were significantly higher than a physiological norm. In an overview, published by Shaffer F. and Ginsberg J.P. in 2017 [6] it is mentioned that higher HRV is usually associated with pathological states and is strongly linked with mortality. In contrast to group with very low SI, the rescuers with $\mathrm{SI} \geq 200$ were found out to have decreased HRV and prevalence of sympathicotonia even before the competi- 
tions. According to the obtained results, both subgroups of rescuers should be included in the risk group of disadaptation. The last one can be explained by the theory proposed by $\mathrm{D}$. Vaillancour and K. Newel [20]. They suggested that healthy biological systems exhibit spatial and temporal complexity whereas a disease can involve either its loss or increase. Based on the obtained results we can recommend the assessment of the SI in periodical medical examinations for distinguishing of groups of rescuers with the risk of disadaptation and cardiovascular disorders. In addition, biological age and ageing rate which were found to be closely related to different HRV parameters (Table 5) can be used as additional indices for the complex assessment of the workers' health state.

\section{CONCLUSIONS}

Emotional and physical loads caused by performance of standard competitive operations for the elimination of a simulated emergency situation by rescuers led to an increase in the sympathetic effect in the regulation of cardiac rhythm and to the growth of the strain of vegetative regulation. the signs of neuroemotional stress were found in the majority of the study group even before the competitions. The Stress Index was the most sensitive component, correlating with the majority of HRV parameters; rescuers with average levels of SI $(50 \leq \mathrm{SI} \leq 200$ units $)$ demonstrated the most sufficient physiological response, while workers with low and high values of SI were referred to the risk groups of disadaptation, cardiovascular diseases and mortality. Biological age and the Stress Index can be recommended as additional parameters to the medical service of rescue brigades for assessing adaptive reserves of the body in periodical medical examinations

The authors would like to express gratitude to Volodymyr Petrukchin and Glushkov Institute of Cybernetic of NAS of Ukraine for technical support of our research.
The authors of this study confirm that the research and publication of the results were not associated with any conflicts regarding commercial or financial relations, relations with organizations and/or individuals who may have been related to the study, and interrelations of coauthors of the article.

\section{I.А. Мищенко ${ }^{1}$, О.І. Соловйов ${ }^{2}$, К.О.Апихтін ${ }^{2}$ \\ ВАРІАБЕЛЬНІСТЬ СЕРЦЕВОГО РИТМУ ГІРНИЧОРЯТУВАЛЬНИКІВ В УМОВАХ ЛІКВІДАЦІї ЗМОДЕЛЬОВАНОЇ НАДЗВИ- ЧАЙНОЇ СИТУАЦІї}

Короткохвильовий запис показників варіабельності серцевого ритму (ВСР) був зроблений у групі гірничорятувальників $(\mathrm{n}=18$, середній вік $29 \pm 1,4$ років, який коливався від 22 до 44 років) до та після ліквідації змодельованої надзвичайної ситуації, організованої у вигляді змагань. Впродовж двох годин працівники використовували спеціальне рятувальне обладнання, надавали першу медичну допомогу для умовних постраждалих та виконували різноманітні тактичні завдання. Досліджувана група була поділена на 3 підгрупи відповідно до рівня стрес-індексу (SI). Проаналізовано спектральні та частотні показники ВСР, розраховано значення біологічного віку, належного біологічного віку та швидкості постаріння працівників. Показано, що переважна більшість гірничорятувальників демонструвала ознаки нервово-емоційного напруження ще до початку змагань. Емоційні та фізичні навантаження, викликані ліквідацією змодельованої надзвичайної ситуації, збільшували напруження вегетативної регуляції і призводили до їі зростання наприкінці змагань. У рятувальників з середнім рівнем SI спостерігалася найбільш адекватна фізіологічна відповідь, у той час як обстежені з низьким та високим значенням цього показника були віднесені до груп ризику з дезадаптації та серцево-судинних захворювань. Біологічний вік працюючих достовірно перевищував популяційну норму і разом з SI може бути рекомендований для використання під час періодичних медичних оглядів. Ключові слова: дезадаптація; варіабельність ритму серця; гірничорятувальники; фактори ризику; стрес-індекс. ${ }^{1}$ Івано-Франківський національний медичний університет; e-mail: kolg.ira21@gmail.com;

${ }^{2}$ Державна установа "Інститут медицини праці АМH Україні ім. Ю.І. Кундієва”, Київ

\section{REFERENCES}

1. How the ILO helps prevent mining accidents in Ukraine. ILO. https://www.ilo.org/global/about-the-ilo/newsroom/ features/WCMS_633923/lang--en/index.htm.

2. Ramirez-Villegas JF, Lam-Espinoza E, Ramirez-Moreno 
DF, Calvo-Echreverry PC. Heart Rate Variability Dynamics for the Prognosis of Cardiovascular Risk. PLoS ONE. 2011;6(2):e17060.

3. Birukova EA. Heart rate variability of subjects with different types of vegetative regulation under the influence of controlled breathing with individually chosen frequency [summary of dissertation]. Simferopol: Taurida National V.I. Vernadsky University; 2010. 22. [Ukrainian].

4. Sosnovskyi VV, Pastukhova VA, Ilyin VN. Characteristics of functional states of the organism's regulatory systems in middle- distance runners during long-time adaptation to conditions of mid-range altitude. Fiziol $\mathrm{Zh}$. 2018;64(6):55-62.

5. Task Force of the European Society of Cardiology and the North American Society of Pacing and Electrophysiology. Heart rate variability standards of measurement, physiological interpretation, and clinical use. Circulation.1996;93:1043-65.

6. Shaffer F, Ginsberg JP. An Overview of Heart Rate Variability Metrics and Norms. Frontiers in Public Health.2017; 5:258.

7. Sassi R, Cerutti S, Lombardi F, Malik M, Hiukuri HV, Peng CK, Schmidt G, Yamomoto Y. Advances in heart rate variability signal analysis: joint position statement by the e-Cardiology ESC Working Group and the European Heart Rhythm Association co-endorsed by the Asia Pacific Heart Rhythm Society. Europace. 2015; 17(9): 1341-53.

8. Baevsky RM, Chernikova AG. Heart rate variability analysis: physiological foundations and main methods. Cardiometry. 2017; 10:66-76.

9. Voytenko VP. Biological age. In: Aging Biology. Leningrad, Nauka publ. 1982; 102-15. [Russian].

10. Hadase M, Azuma A, Zen K, Asada S, Kawasaki T, Kamitani T, Kawasaki S., Sugihara H, Matsubara H. Very low frequency power of heart rate variability is a powerful predictor of clinical prognosis in patients with congestive heart failure. Circ J. 2004;68:343-7.

11. Nunan D, Sandercock GR, Brodie DA. A quantitative systematic review of normal values for short-term heart rate variability in healthy adults. Pacing Clin Electrophysiol. 2010;33:1407-17.

12. Tomaskova H, Jirak Z, Lvoncik S, Buzga M, Zavadilova V, Trlicova M. Health status and physical fitness of mines rescue brigadesmen. Int J Occup Med Environ Health. 2015; 28(3):613-23.

13. Mykhailov V. Heart rate variability: experience in practical application of the method. Ivanovo. 2003; 290.

14. Moldabek G. Heart rate variability indicators in patients with hypothyroidism. Med and Health Sci J. 2011;6: 127-31.

15. Ponikowski P, Anker SD, Chua TP, Szelemej R, Piepoli M, Adamopoulos S, Webb-Peploe, Harrington D, Banasiak W, Wrabec K, Coats AJ. Depressed Heart Rate Variability as an Independent Predictor of Death in Chronic Congestive Heart Failure Secondary to Ischemic or Idiopathic Dilated Cardiomyopathy. Am J Cardiol.1997; 79(12):1645-50.

16. Schmidt H, Muller-Werdan U, Hoffmann T, Francis DP, Piepoli MF, Rauchhaus M, Prondzinsky R, Loppnow H, Buerke M, Hoyer D, Werdan K. Autonomic dysfunction predicts mortality in patients with multiple organ dysfunction syndrome of different age groups. Crit Care Med.2005;33: 1994-2002.

17. Dimitriev DA, Saperova EV. Heart rate variability and blood pressure during mental stress. Ross Fiziol $\mathrm{Zh}$ Sechenova. 2015; 101(1):98-107.

18. Dyachkova TV, Berseneva IA, Zavaltseva OA, Mishina OS. Study of Regulatory Mechanisms of Activity of Cardiovascular System by Method of Mathematical Analysis of Heart Rhythm in Workers of Chemical Manufactures. IOP Conf. Ser.: Earth Environ. Sci. 2018;115(1).

19. Nelson RJ. Biology of Aggression. Oxford University Press, New York. 2005:451

20. Vaillancourt D, Newell K. Changing complexity in human behavior and physiology through aging and disease. Neurobiology Aging. 2002;23:1-11.

Received 05.03.2019 